Gazi University
Journal of Science
http://dergipark.gov.tr/gujs

\title{
Evaluation of Buildings and Building Physics Master's Thesis in Architectural Education in Turkey
}

\author{
Ozlem AYDIN ${ }^{1}$, Semiha ISMAILOGLU²*(i), Ayca AKKAN ${ }^{3}$ (i) Ebru SANLI $^{1}$ \\ ${ }^{1}$ Karadeniz Technical University, Architecture Department, 61080, Trabzon, Turkey \\ ${ }^{2}$ Atatürk University, Interior Architecture Department, 25240, Erzurum, Turkey \\ ${ }^{3}$ Recep Tayyip Erdoğan University, Architecture Department, 53100, Rize, Turkey
}

\author{
Highlights \\ - Between the years 2000-2018 master's thesis completed at universities in Turkey were examined. \\ - Master theses in the field of building and building physics in architecture were analyzed. \\ - Data were obtained with an exceptionally large and comprehensive study. \\ - This study aims to bring different perspectives to future research in the field of architecture.
}

Article Info

Received: 19 Dec 2020

Accepted: 14 Mar 2021

Keywords

Architectural

education

Master's thesis

Bibliometric analysis

Content analysis

Building physics

\begin{abstract}
The study aims to create a resource by scanning the data on Masters theses on construction and building physics under the department of architecture in universities in Turkey between 2000 and 2018. The study is important because there are currently no printed and digital literature reviews on this subject available. The sampling of the study consists of Master's theses from the department of architecture in the HEC National Thesis Center system. In the study, were examined 850 accessible Master's theses on the topic of construction and building physics from the departments of architecture of universities in Turkey. The language, year, city, university, title, method, and keywords of the theses were evaluated using a bibliometric and content analysis method. In this context, the study aims to create a source for the research and to guide the selection of methods and topics. It was observed that the subjects addressed in the theses from the construction technology department in architecture at a graduate education level vary depending on the developing technology and needs, and studies on energy and acoustics have increased.
\end{abstract}

\section{INTRODUCTION}

Architecture undergraduate and graduate education in Turkey is provided at many state and foundation universities. Universities that provide the necessary conditions to open graduate education programs in an academic sense offer master's and doctorate degrees. After undergraduate education, graduate education continues with a master's degree or an integrated doctorate. The period for architectural education in Turkey is four years. At the end of this period, an architect diploma with signed authorization is attained. Students who fulfill certain criteria after their undergraduate degree (having the university's required score in ALESAcademic Personnel and Postgraduate Education Entrance Exam- and ÜDS- Interuniversity council foreign language exam- exams) can receive the title of architect after receiving academic education for two more years [1]. This program, also known as master's education, is a form of higher education aimed at realising the results of education and research. Master's education is completed by using information from the field of education to prove a situation with a scientific product. After successful completion of the thesis defense, the person gets the title of Master of Architecture. In master's study, the person may not necessarily have to reach an original result and can obtain information from previous studies and interpret it in their own manner and style [2]. 
Architectural education in Turkey first started in the Sanayi-i School of Fine Arts in 1883. This institution took the name of the State Academy of Fine Arts in the Republican period (1928), and then Mimar Sinan University (1982), and continued its architectural education until today [3]. Since 1940, the study of architecture has been offered in different cities in Turkey, especially Istanbul. Considering the results of 2017 settling in Turkey and the The Turkish Republic of Northern Cyprus 's degree in architecture that is 108 the number of universities. The number of universities offering graduate education in Turkey is 61 , as of 2018. Postgraduate education periods are at least two years for the master's program and at least four years for the doctoral program. Four-year architecture graduates can apply to the Master of Architecture program. Candidates who do not have an architectural license must attend a one-year scientific preparation program and can then continue their graduate program if they are successful.

In universities where there are departments of architecture, the branch of architecture is divided into different disciplines. In this sense, in general, scientific branches, such as building, construction, architectural design, environmental control, and building technologies, project and construction management, architectural history, art history, urbanism, architectural conservation, and restoration are included in architectural departments. Each branch of science shows its limits by writing theses on topics in their field. Examining the content of the theses allows for knowing under which discipline the researchers wrote. In this context, the topics that researchers are working on vary according to their interests. However, from time to time, some issues are considered, allowing them to be studied more in the process. In addition, although there are studies in different fields, some theses may also be related to more than one discipline in terms of their content. The physical environment is defined in the discipline of architecture as a scientific field. It is the field where works are carried considering topics such as structure, acoustics, thermal comfort, energy, sustainability, materials, and carrier systems. The subjects and methods of the studies in this field vary depending on the changing living conditions, disasters, developments in science, and technology. The use of research methods and techniques varies depending on the study topics in the field of building and building physics. Especially in quantitative research, experimental studies involving model development, simulation, problem-solving, measurement, and application studies are carried out. As a tool of data collection in the field of research, it provides the opportunity to make traditional computer-aided calculations and simulations (resemble/re-suggest/choose the most suitable) and offer many quantitative and linear options together. Using computer technology as a tool provides support for experimental and institutional studies in terms of producing models, offering solution options, and sizing following building standards and calculations.

There are many studies examining theses in different disciplines. It has been observed that research examining postgraduate studies in the branches of architecture and interior architecture has carried out in recent years. However, there is no study for the research of theses involving building physics studies in the field of architecture. In the study of Anay et al. (2018) in the field of architecture, he evaluated his doctoral theses published between 1995-2014 using the content analysis method. In this study, Ph.D. theses consider the number, language, university, subject, content, theme/area, resource, method, and the technical analysis performed according to the year [4]. Varol and Varol (2020), using a descriptive scanning model, studied the proficiency of doctoral thesis studies in the field of interior architecture, categorized according to imprint information (type, year, university, and institute) and content information (method, data collection tools, and study topics; [5]. In the literature research, it was observed that studies the graduate theses were mostly done in the field of interior architecture. Aydıntuğ (2018), "1989-2017 year in universities in Turkey Investigation of Interior Architecture and Environmental Design Studies Subject of Dissertation and Content" in the study titled, bibliometric data in four different university graduation thesis (universities, institutes, departments, year of publication, and publication status and program) and produced numerical data. In this study, the distribution of the title of the postgraduate theses published and the relation between the keywords used and the rate of keywords used by the universities were analyzed [6]. Approval and et al., in their study, examined the distribution of interior architecture Doctorate and Master's theses according to the subject areas between 2004-2014 [7]. In a study in the field of landscape architecture, the formal and contextual features (author's name, thesis name, year, university, institute, department, subject, application area, and method) of the doctoral theses completed between 2010-2018 were evaluated and the deficiencies and deficiencies in the studies were revealed [2]. 
The main purpose of this study is to compile literature information by analyzing the completed graduate education theses in the fields of science in architecture and building physics in architecture, and to contribute to architectural education by bringing different perspectives to future studies.

\section{MATERIAL and METHOD}

\subsection{Material}

In this study, postgraduate studies conducted by universities in the fields of construction and building physics from the department of architecture in Turkey were evaluated. In this context, we aimed to investigate the research topics, the field of study, the technical, and method tools, and to guide researchers in this regard. In this study, theses in the field of architecture and building physics in the graduate programs of the department of architecture between the years of 2000-2018 were examined.

Within the scope of the study, completed theses from the department of architecture and building physics in our country were examined. Open access theses determined the limits of the study. In this context, 850 master's theses with data about the study were found online through the HEC (National Thesis Center). In this study, firstly, theses approved by the universities providing postgraduate education between 2000 2018 were examined, and then the theses approved for publication were evaluated.

\subsection{Method}

In this study, the bibliometric scanning and content analysis method were used. In our research, in graduate studies of architecture, bibliometric analyzes of the postgraduate theses in the field of building and building physics based on the city, university, year of publication, and publication language were made. This analysis method is a quantitative research method, and it enables the analysis of various elements of academic publications (author, subject, year, number of pages, references made, etc.) with the help of numerical analysis and statistics [8]. In this study, the titles and keywords of the theses were analyzed using the content analysis method. According to this, the keywords were divided into categories and groupings using themes and concepts. The data were categorized according to these categories and were counted, and the numerical data were obtained. The methods and techniques used in the theses were systematically analyzed according to the scientific research methods and techniques in the literature, and a content analysis was made.

Content analysis is a method that guides researchers to do more useful research, because it allows them to see the trends and interests of research in the field [9]. In this study, bibliometric and content analyses were made of the data of the theses using MS Excel and SPSS programs (percentage and frequency). The quantitative data of the keywords and titles were obtained using the AntConc3.4.4.4 program. When the results obtained in the research were evaluated, the necessity of expanding the fields of study by focusing on different research topics in the field of building physics and directing the researchers to more original subjects was revealed.

\subsubsection{Bibliometric analysis}

Bibliometric analysis is a field based on counting, which is defined as the application of mathematical and statistical methods to other environments [10]. Bibliographic studies reveal a realistic profile of the literature on a discipline; it is a method that provides written documents of the relevant discipline by providing information about the subjects, study intensities, registration, definition, classification, and qualitative analysis of studies in a particular field [11]. In bibliographic analyses, data that do not make sense on their own are brought together and interpreted, and various inferences are made by evaluating these data [12]. These inferences from bibliographic analyzes are data for future studies, but also reveal the profile and study intensities of the subjects [13]. 


\subsubsection{Content analysis}

Content analysis is a method that enables us to determine objectively and systematically the specific and clearly expressed characteristics of a message used in studies that cannot be directly measured and observed, and to make inferences about them [14]. This research method shows researchers trends, interests, and patterns, and suggests research areas that can be useful for this purpose. Content analysis can also be a useful technique that allows for identifying and exploring the focus of an individual, group, institution, or social interest [9]. Berg and Lune expressed content analysis as a careful, detailed, and systematic examination and interpretation of a certain amount of material to draw patterns, themes, assumptions, and meanings [15]. The purpose of this research technique is to teach the concepts and relationships that can explain the data collected. Considering the application of this method, the data are conceptualized, texts are organized, and themes explaining the data are determined [16].). With this method, similar concepts and themes are brought together and grouped, and are transformed into a form that the reader can understand [17]. Content analysis can be either a qualitative or a quantitative type of research, as well as both. While quantitative analysis makes sense of the data by counting textual elements, the qualitative analysis includes the interpretative analysis of the data arranged according to the items in certain content, and the evaluation of the plain words in the analyzed text and the use of these words [15].

\section{THE RESEARCH FINDINGS AND DISCUSSION}

In our study of graduate education research of architecture, bibliometric analyses of the postgraduate theses in the field of building and building physics considering city, university, publication year, and publication language were investigated. The content analysis method of the theses, keywords, thesis title, methods and techniques used, and simulation programs used in the field of building and building physics were evaluated.

The number of theses made in this field in technical universities in our country is higher than in other universities. According to this, between the years 2000 and 2018, 28.7\% (244) of the master's thesis studies were conducted at Istanbul Technical University, 17.29\% (147) at Y1ldız Technical University, 9.88\% (84) at Gazi University, and 6.58\% (56) at Mimar Sinan Fine Arts University (Figure 1).



Figure 1. The Theses Were from The Following Universities 
When the analyzed theses were evaluated according to university cities, 64.7\% (550) of the theses were published in Istanbul and $13.7 \%$ (116) Ankara. In this evaluation, considering the number of universities in metropolitan cities, it is seen that the number of thesis studies is high (Figure 2). In addition, an important factor in the high number of theses made in technical universities is the diversity of branches of science related to building physics. For example, under the Environmental Control and Building Technology graduate program at Istanbul Technical University, there are many areas of building physics (such as air conditioning, lighting, acoustics, materials, building technology, earthquake, ecology, and sustainability).

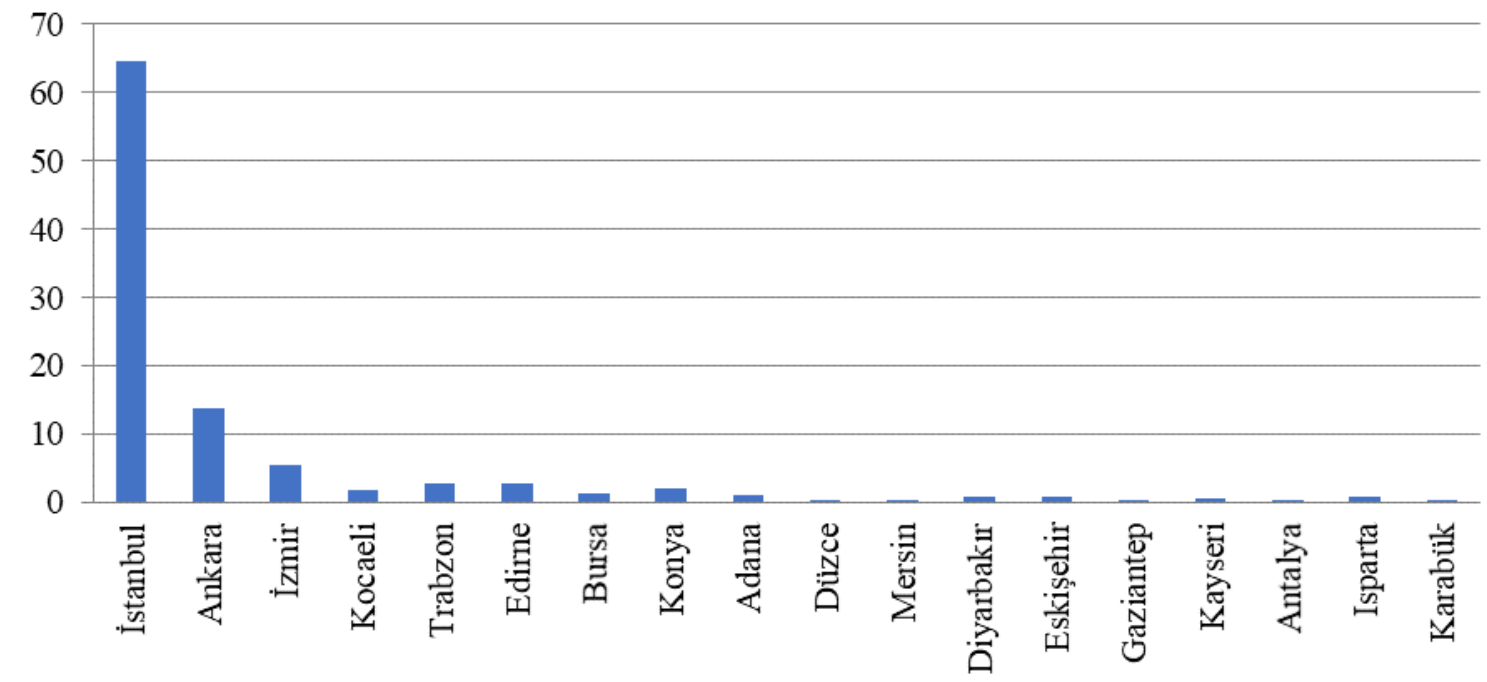

Figure 2. The Theses Examined in This Study Were from The Following Cities

An increase in the number of studies carried out, particularly after 2004, in the field of building and building physics was observed. Accordingly, 12.1\% (103) of the theses made in the field of building and building physics between 2000-2018 were made in 2018 (Figure 3).

20

15

10

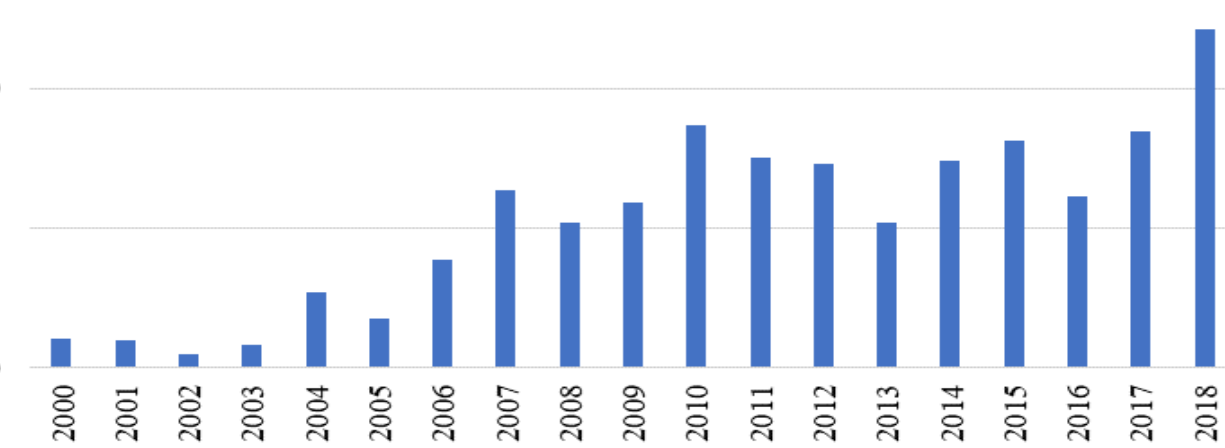

Figure 3. Distribution of The Theses in Building and Building Physics Over the Years

Of the theses examined in the field of building and building physics, 86.9\% (739) were written in Turkish and $13.1 \%$ (111) were written in English (Figure 4). The most important reason why the writing language of theses is mostly Turkish is that the education at universities is in Turkish. Almost all theses written in English are due to the language of instruction being English or the education in this language to a certain extent. 


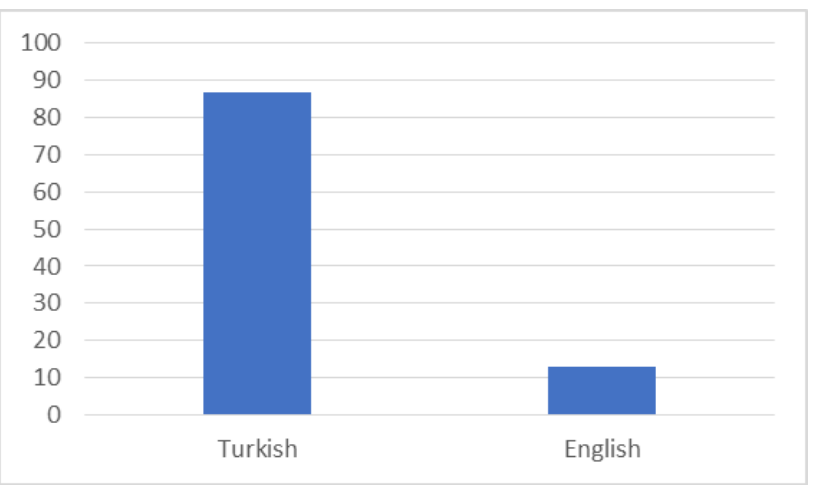

Figure 4. Written Language of The Theses

In this study, the words that made up the titles of the theses, were placed in categories and groupings according to the content analysis, and concepts and themes were formed. When the titles of the theses were analyzed, it was determined that the words "structure", "system", "building", and "energy" were the most used words. The most used 50 words included in the analyzed thesis titles are shown in Figure 5. Among the words used in the thesis titles, "building" was used at a rate of $35 \%$ (300); "building" at $26 \%$ (221); "system" at 21\% (182); "architecture" (168), "energy" (167), and "design words" (152) at 20\%; and "residential" (100), "sustainable" (96), and "front words" (88) at a rate of 12\%-10\% (Figure 5).

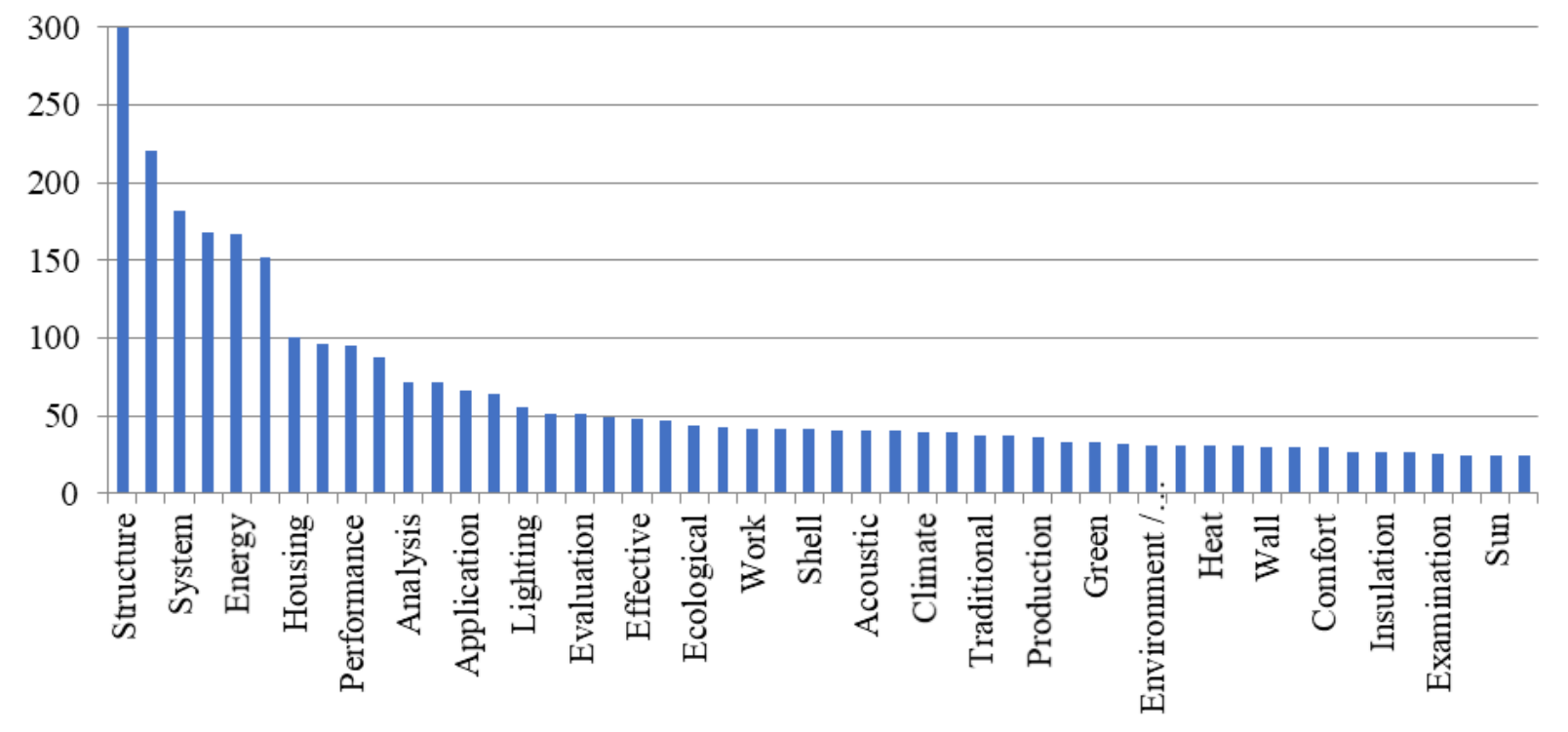

Figure 5. Most-Used Words in The Titles of The Theses

When we examined the theses in the field of building and building physics in the architecture department of universities between the years 2000-2018, the keywords and word groups of the were analyzed using AntConc 3.4.4.0 program. The keywords of the theses examined were entered into this program as data, and the most-used words were determined. Accordingly, numerical data were obtained by grouping the first 100 words and the word groups used the most. In the theses examined, it was determined that keywords such as "sustainability", "energy", and "ecology" were used more (Figure 6). In Figure 6, the first 50 words and word groups analyzed are shown. In this evaluation, it was determined that the word "energy" was used at a rate of 20\% (172); "sustainability" at 16\% (143); and "ecology" (54), "building" (52), "acoustic" (51), and "facade" (40) were the most-used words at a rate of $6 \%$. 


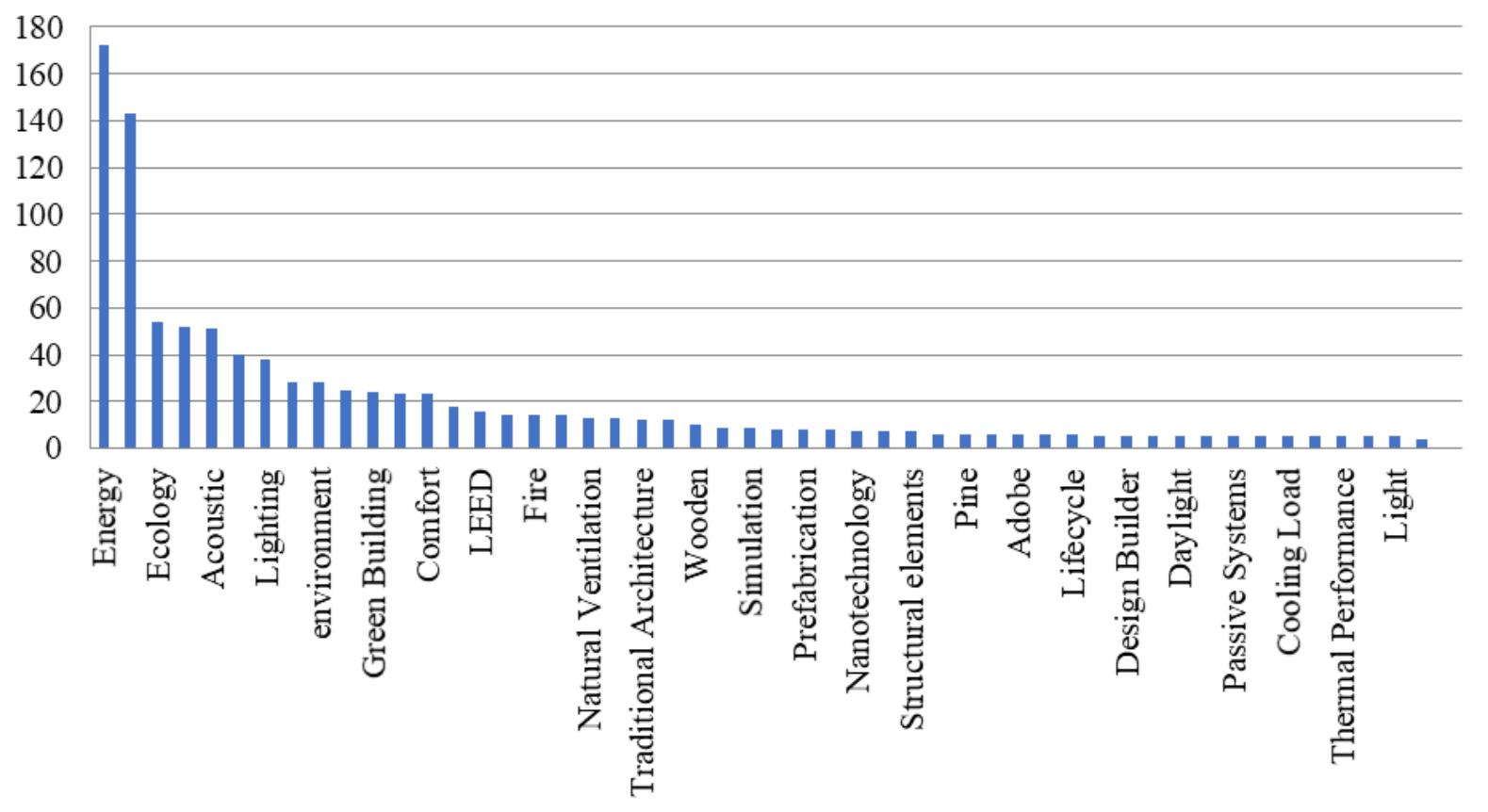

Figure 6. Most-Used Keywords in The Theses

To determine which subjects were the most studied in the field of building and building physics according to year, the keywords and word groups of the theses were analyzed using the AntConc 3.4.4.0 program. Accordingly, the most used words were grouped into ten titles. What the study subjects were according to year was revealed with the obtained data. According to this, "construction/building", "energy", "sustainability", "ecology", and "materials issues" were the most common topics over the years (Figure 7).

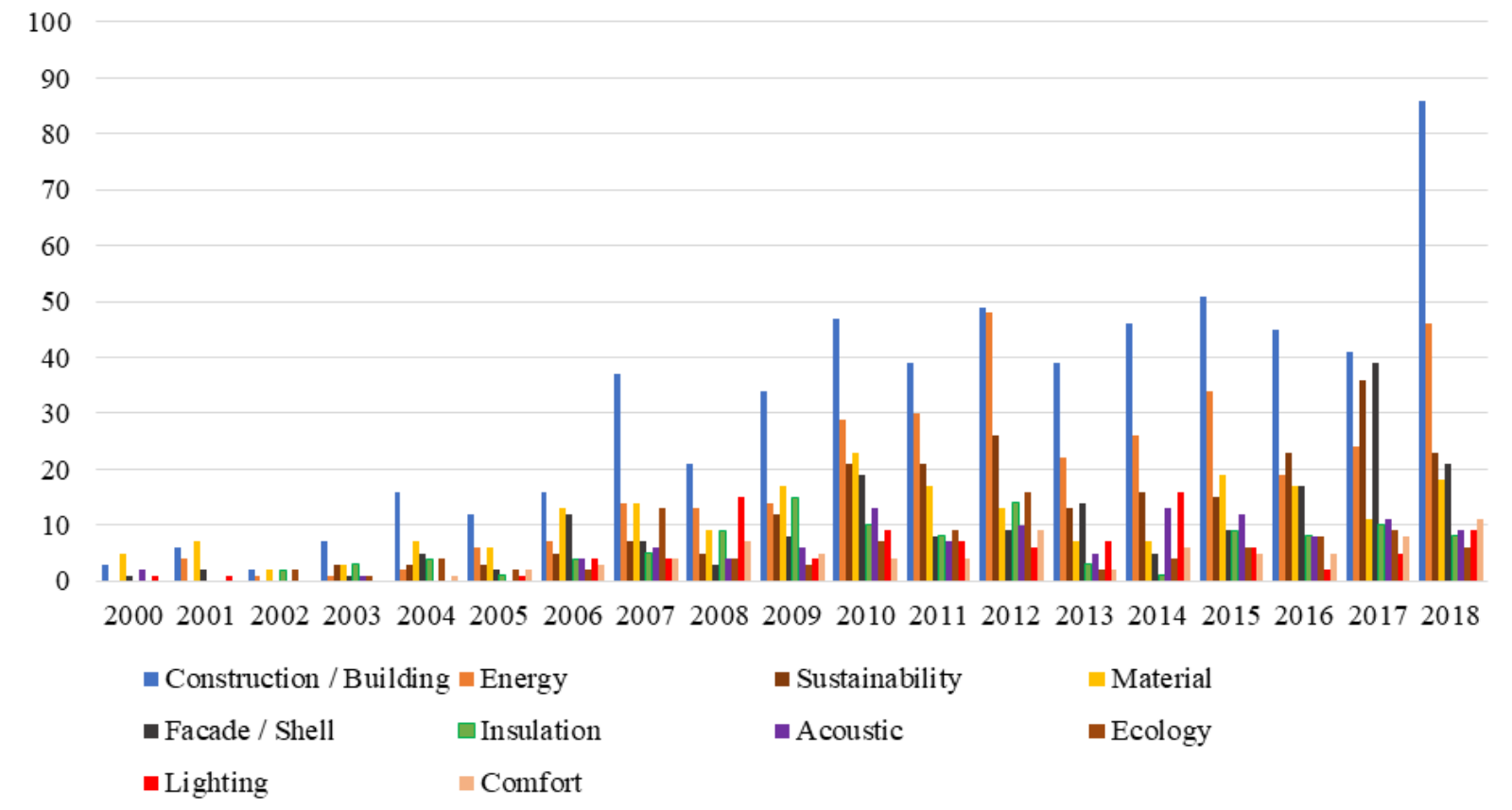

Figure 7. Distribution of Subjects of The Theses Over the Years

When the content analysis of the theses examined the research type, 55.6\% (472) of the theses were completed using qualitative assessments, 35.7\% (304) quantitative, and 8.7\% (74) using both (Figure 8). The most important feature that distinguishes building physics from other branches of science; more quantitative research (experiment, measurement, calculation, etc.) is done in this field. In the theses made in the field of science, in addition to document scanning, interview, visual analysis, calculations, simulation 
programs, measurement, and experimental studies were used as the second method.

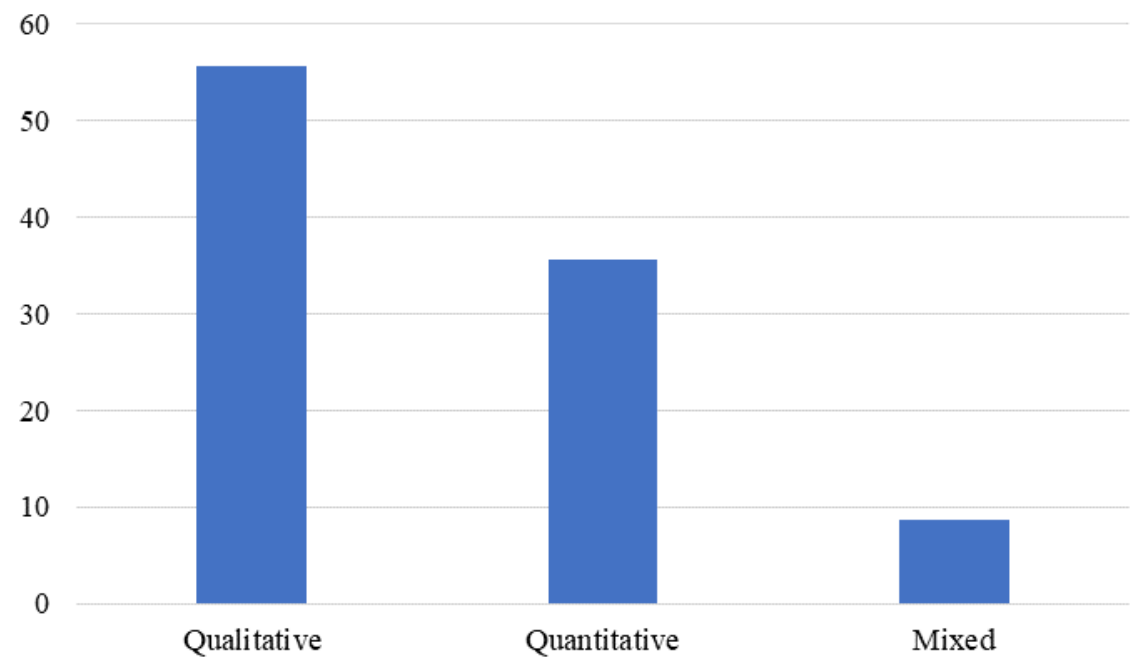

Figure 8. Research Methods of the Theses

In graduate studies, mostly qualitative (document scanning, observation, and interview) research methods are used. However, the content of the research starts to change depending on the developments and needs in education and daily life. While the number of qualitative studies according to research type is high, the number of theses completed using quantitative research has been increasing gradually since 2006 (Figure 9). Since the beginning of the 2000 s, with the enactment of laws and regulations within the scope of energy efficiency in buildings in the world and our country, many studies have been started in this field. In this context, the conservation of energy, calculations, experimental studies, and use of simulation methods in postgraduate education has started to increase since then

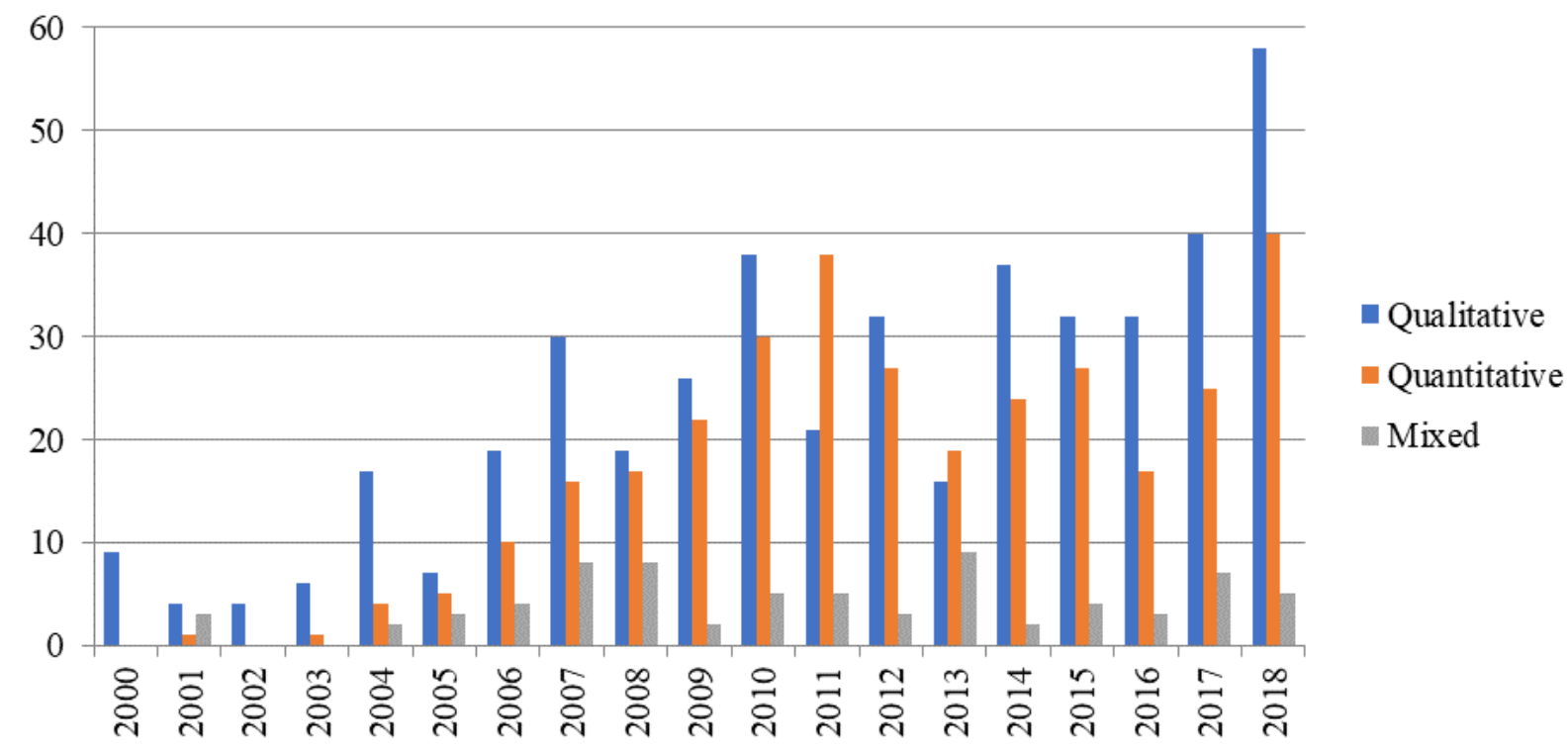

Figure 9. Distribution of Research Methods Used in the Theses over the Years

In this study, the research methods and techniques were analyzed by dividing them into various titles according to the intensity of use. Accordingly, literature review studies were evaluated and calculated using the document scanning method. Studies conducted with the interview method were analyzed under separate headings, as questionnaires and semi-structured interviews. The simulation method, which evaluated the method technique based on experiments and measurements, was evaluated separately from the experimental technique depending on the intensity of use in thesis studies in the field of building and 
building physics. Accordingly, $43.2 \%$ (364) of the examined theses were documented to have used the scanning method, $19.8 \%$ (232) unstructured conversation (simulation), 18.8\% (188) experiments, $11.8 \%$ (124) survey, 5\% (59) analogy and 1.1\% (13) observation (Figure 10).

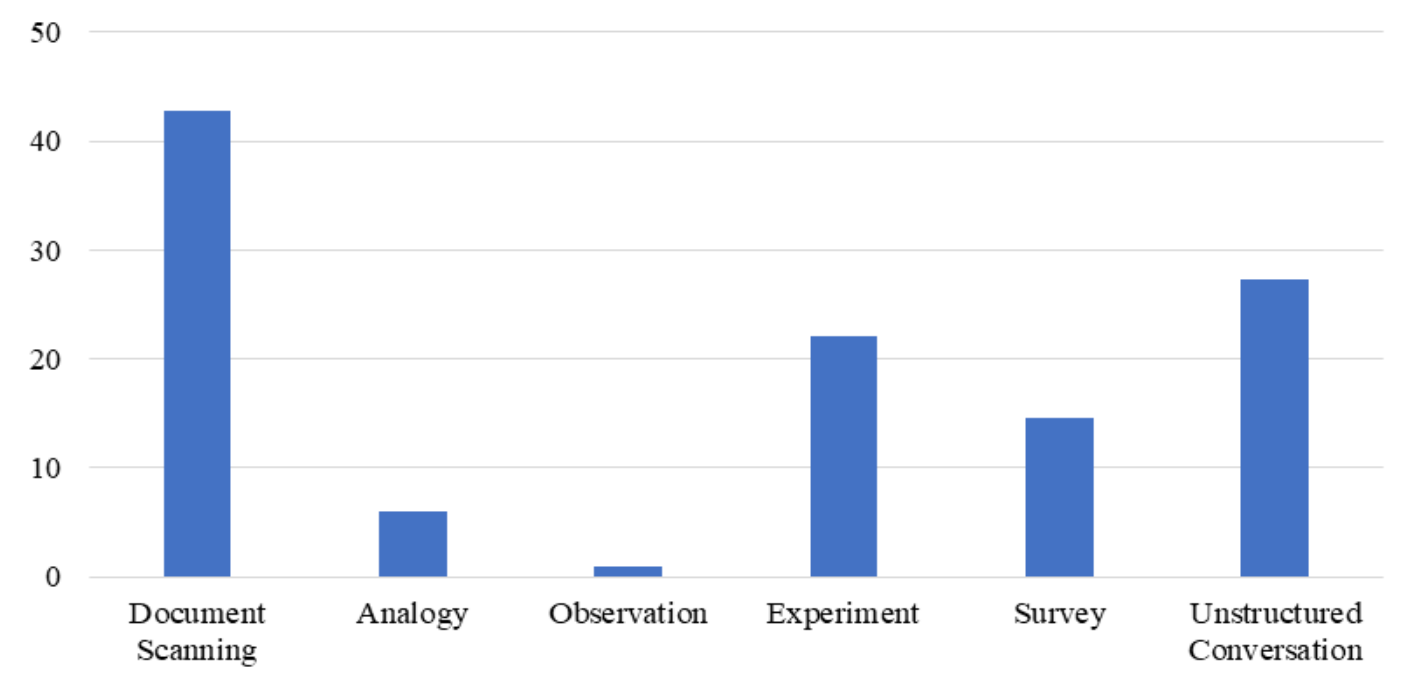

Figure 10. Distribution of Research Techniques Used in the Theses

When the research methods and techniques of the examined master theses were analyzed according to year, it was found that the document scanning method was used more than the other methods. It was determined that experimental studies (experiment, measurement, and simulation) as a type of quantitative research started to be done more, particularly since 2006. After the document scanning technique, the most used method was the simulation technique (Figure 11).



Figure 11. Distribution of The Research Techniques Used in The Theses Over the Years

The most used software in the thesis studies was simulation programs that performed energy or dynamic system analyses. Some software can work with different types of input (fluid and energy), while others are programs that only allow for working in limited spaces (such as sound and light). Some computer programs that can enable work on building design to determine the safety of a building and its user under constant load, against seismic, temperature, wind, and side Earth loads were also used. When the simulation 
programs used in theses were analyzed, the most widely used energy simulation programs were DesignBuilder (50), EnergyPlus (15), Ecotect, TS825 Thermal Insulation Calculation (11), Bep-TR (8), Odeon (32), Dialux (17), and Relux (5) (Figure 12).

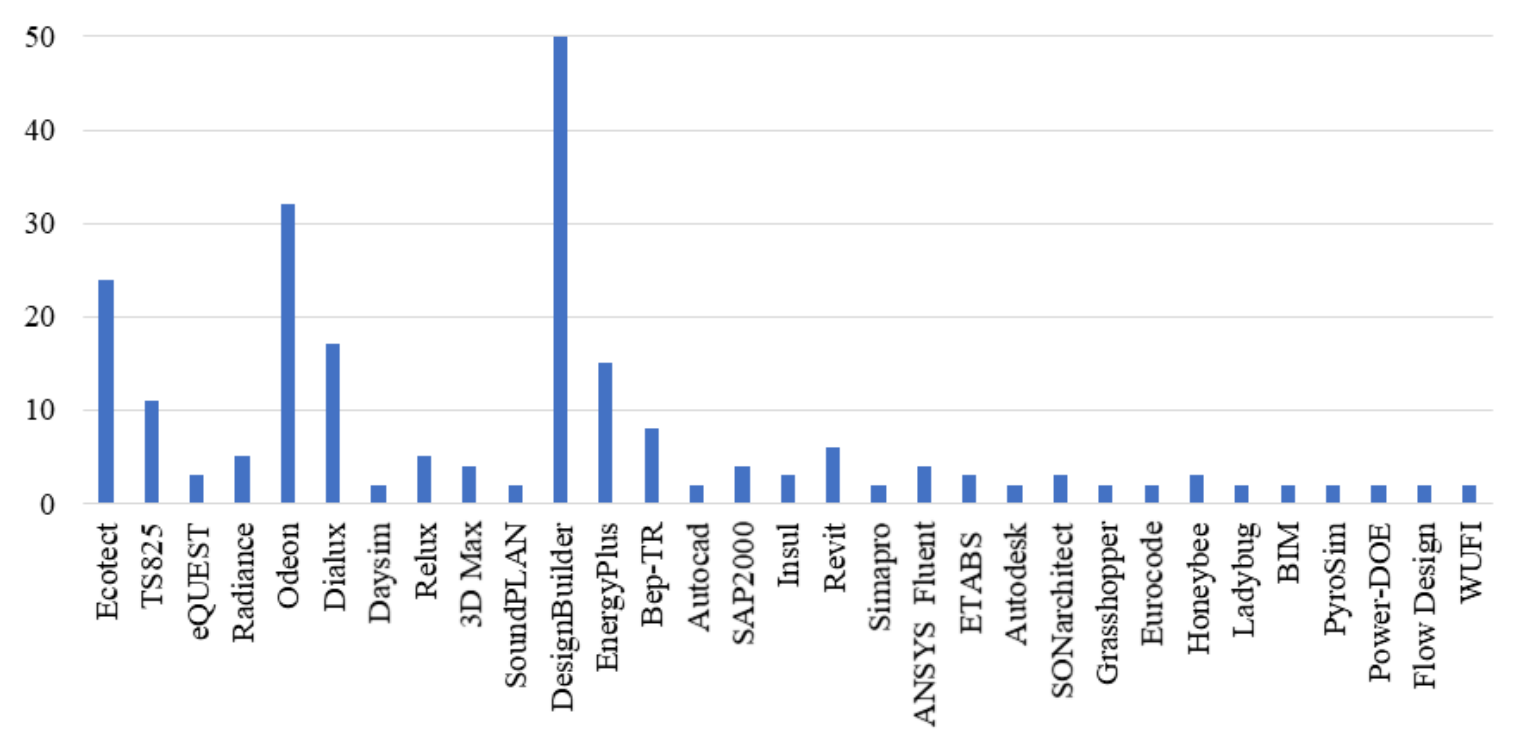

Figure 12. Simulation Programs Used in the Theses

\section{RESULTS}

In this study, an evaluation of the theses from the university departments of architecture in Turkey between the years 2000-2018 was made. The theses were determined within the scope of the research from the HEC National Theses Center examined online. Statistical evaluations of the theses were presented with the data obtained using the bibliometric and content analysis methods. . In this study, the department of architecture at universities in Turkey, a comprehensive content analysis of the arguments made in the field of building physics is made. In this context, basic research topics and contents were determined as a useful research tool to define the knowledge base of theses. When the results of this study were evaluated in general, the results are as follows.

- Most of the theses made within the scope of the research topic were made in technical universities in Istanbul. Istanbul Technical University and Y1ldı Technical University constitutes approximately 50\% of the theses. The fact that the universities are in big cities and that there are various branches of science in the field of building physics in these universities increase the number of theses in this field. The fact that there are graduate programs related to building physics under the department of architecture and the number of academicians make graduate education more attractive in these universities. The written languages of the examined theses are Turkish and English, with $86 \%$ being written in Turkish. The fact that $95 \%$ of the undergraduate and graduate programs of the universities (state, foundation) in our country are made only in Turkish is effective in this.

- It is seen that the number of studies in the field of building and building physics has increased in recent years. At this point, in the world as well as in the subject of this study, Turkey, for energy conservation, sustainability, and earthquake, studies in the academic field for developing materials and systems technology are said to be effective. In this context, it is particularly important to use these issues efficiently, especially in the protection of the environment, in the social and economic field, and the existing potentials.

- Through the content analysis of the words that make up the titles of the theses and the keywords of the theses, the most used words are concentrated within the framework of the subjects that constitute the scope of the study of this field. Accordingly, the most used title words are "structure", "building", and "system", and the most frequently used keywords are "energy", "sustainability", and "ecology". 
- For qualitative research, methods of document scanning, observation, interview, and document analysis have been performed to collect data. The rate of qualitative studies using these methods is higher in the master's theses examined in this context. As for the quantitative research type, survey, measurement, and experimental techniques have been used to obtain quantitative data. In this study, quantitative studies using these techniques as research methods and theses using both types of research are also determined.

- The theses in which experimental studies were carried out are evaluated under two headings, as experiments (experimental work in the laboratory, measurement, etc.) and methods using the simulation technique. As a result, it is seen that the simulation technique, in which simulation programs used as a data collection tool, is preferred more than the experimental method. Building simulations are divided into three, as modeling tools that can evaluate the information such as size and shape during the design of the building, design tools that help the development of design alternatives, and analysis tools that evaluate building performance approaches (energy flow, structural strength, acoustics, etc.) [18]. Simulation programs are preferred because the current situation can be determined, and re-proposal can be made, the data can be obtained quickly, and they save time.

Theses, which are accepted as the most important output of the graduate education process, affect the authors' choice of future academic fields of study in terms of the subjects they deal with while contributing to the development of the literature and their application areas. The variety of topics covered in the theses is as essential as the number of master theses prepared in disciplines. While the number of theses gives an idea about the amount of scientific knowledge produced by the theses prepared in that field, the diversity of master theses can give an idea about the scope of scientific knowledge generated.

It is thought that this study will contribute to the benefit of academic education and application, to train qualified researchers and to develop data that will support scientific works. In this context, universities need to determine their fields of study in line with the developing technology, needs, and demands of postgraduate education. It is thought that the work will benefit the work still to be done in terms of creating and developing knowledge on building and building physics within the field of architecture. It may be possible to carry out joint studies to support effective support in the field especially on energy and sustainability issues and to support relevant institutions and organizations in this regard

\section{CONFLICTS OF INTEREST}

No conflict of interest was declared by the authors.

\section{REFERENCES}

[1] Oğuz, P. G., Özyılmaz, H., Dağtekin, E., "Dicle Üniversitesi’nde Mimarlık Eğitimi”, Uludağ Üniversitesi Mühendislik-Mimarlık Fakültesi Dergisi, 13(2): 1-13, (2008).

[2] Özkan, F., Gül, A., "Peyzaj Mimarlı̆̆ı Ana Bilim Dalında Yapılan Doktora Tezlerinin İrdelenmesi”, Türkiye Peyzaj Araştırmaları Dergisi, 2(1): 28-14, (2019).

[3] Dostoğlu N., Bilsel C., "2003 Yılında Türkiye'de Mimarlık Eğitimi: Sayısal Veriler Üzerinden Bir Durum Saptaması", Mimarlık Dergisi, 314, (2003).

[4] Anay, H., Özten, Ü., Anay, Ö., M., Acar, Y., "Türkiye'de Mimarlık/Mimari Tasarım Doktora Araştırmalarına Dair Bir İnceleme”, Yükseköğretim ve Bilim Dergisi, 8(3): 488-501. DOI: 10.5961/jhes.2018.290, (2018).

[5] Varol, A., Varol, B. E., "İç Mimarlık Alanında Yapılmış Doktora / Sanatta Yeterlik Tez Araştırmaları Üzerine Bir Tarama Çalışması", The Turkish Online Journal of Design Art and Communication, 10(1): $1-15,(2020)$. 
[6] Aydıntuğ, E., “Türkiye'deki Üniversitelerde 1989-2017 Yıllarında İç Mimarlık ve Çevre Tasarımı Alanında Yapılan Tez Çalışmalarının Konu ve İçerik Açısından İncelenmesi”, Yüksek Lisans Tezi, Başkent Üniversitesi, Sosyal Bilimler Enstitüsü, Ankara, (2018).

[7] Onay, S. N., Özkan, T., Özgan, S. Y., “Türkiye'de İç Mimarlık Alanında Yapılan Lisansüstü Tezlerin Başlıca Araştırma Alanları ve Konular Bağlamında İrdelenmesi”, Ulusal İç Mimarlık Lisansüstü Eğitim Kongresi-I, İstanbul, (2015).

[8] Yozgat, U., Kartaltepe, N., "Ulusal Yönetim ve Organizasyon Kongre Kitaplarında Yer Alan Bildirilerin Bibliyometrik Profili: Örgüt Teorisi ve Örgütsel Davranış Bildirileri Üzerine Bir Araştırma", Osmangazi Üniversitesi İ̈BF Dergisi, 4(1): 149-165, (2009).

[9] Cavitt, M. E., "A Content Analysis of Doctoral Research in Beginning Band Education, 1958-2004", Journal of Band Research, 42(1): 42-58, (2006).

[10] Pritchard, A., "Statictical bibliography or bibliometrics?", Journal of Documentation, 25(4): 348- 349, (1969).

[11] Turan, A., “Turizm Konulu Yüksek Lisans Tezlerinin Bibliyometrik Özellikleri (1984-2013)”, VII. Lisansüstü Turizm Öğrencileri Araştırma Kongresi, Bildiriler Kitabı, 3-15, (2014).

[12] Gökuç, T. Y., "Yönetimsel Modaların Yapım Yönetimi Alanında Bibliyografik Yöntemle İncelenmesi”, Yüksek Lisans Tezi, Fen Bilimleri Enstitüsü, Balıkesir Üniversitesi, Balıkesir, (2006).

[13] Cevizkaya, İ. A., "Turizm Alan Yazınında Engelliler İle İlgili Çalışmaların Bibliyometrik Profili (2000-2013)”, Gazi Üniversitesi Turizm Fakültesi Dergisi, 2: 101-108, (2014).

[14] Doğru, M., Gençosman, T., Ataalkın, A.N., Şeker, F., "Fen Bilimleri Eğitiminde Çalış1lan Yüksek Lisans ve Doktora Tezlerinin Analizi”, Türk Fen Eğitimi Dergisi, 9(1): 50-63, (2012).

[15] Berg, B. L., Lune, H., "Qualitative Research Methods for the Social Sciences", 9. Baskıdan Çeviri, Çeviri Editörü: Asım Arı, Konya: Eğitim Yayınevi, 344-353, (2019).

[16] Böke, K., Başıüyük, O., "Sosyal Bilimlerde Araştırma Yöntemleri”, 4. Baskı, İstanbul: Alfa Yayınlar1, 351, (2014)

[17] Göktaş, Y., Küçük, S., Aydemir, M., Telli, E., Arpacık, Ö., Yıldırım, G., Reisoğlu, İ., “Türkiye’de Eğitim Teknolojileri Araştırmalarındaki Eğilimler: 2000-2009 Dönemi Makalelerinin İçerik Analizi”, Educational Sciences: Theory and Practice, 12(1): 191-199, (2012).

[18] Hendricx, A., “A Core Object Model for Architectural Design”, PhD Thesis, Catholic University Louvain, Department of Architecture, Belgium, (2000). 